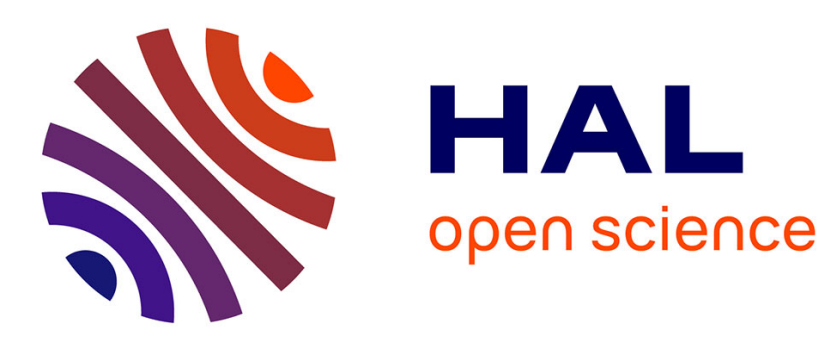

\title{
Can artificial intelligency revolutionize drug discovery?
}

Jean-Louis Kraus

\section{To cite this version:}

Jean-Louis Kraus. Can artificial intelligency revolutionize drug discovery?. AI \& Society: Knowledge, Culture and Communication, 2019, 10.1007/s00146-019-00892-0 . hal-02443859

\section{HAL Id: hal-02443859 https://hal-amu.archives-ouvertes.fr/hal-02443859}

Submitted on 17 Jan 2020

HAL is a multi-disciplinary open access archive for the deposit and dissemination of scientific research documents, whether they are published or not. The documents may come from teaching and research institutions in France or abroad, or from public or private research centers.
L'archive ouverte pluridisciplinaire $\mathbf{H A L}$, est destinée au dépôt et à la diffusion de documents scientifiques de niveau recherche, publiés ou non, émanant des établissements d'enseignement et de recherche français ou étrangers, des laboratoires publics ou privés. 


\title{
Can Artificial Intelligency revolutionize Drug Discovery?
}

\author{
Jean-louis Kraus \\ Professor Aix Marseille University \\ Institut de Biologie du Développement de Marseille (IBDM) \\ CNRS-Inserm-Aix Marseille Université. \\ Campus de Luminy, case 907, 13288 Marseille Cedex . \\ France \\ Email: jean-louis.kraus@univ-amu.fr
}

\begin{abstract}
Artificial Intelligency, can bring speed and reliability to drug discovery process. It represents an additional intelligence, which in any case can replace the strategic and logic creative insight of the medicinal chemist who remains architect and molecule master designer.

In terms of drug design, artificial intelligency, deep learning machines, and other revolutionary technologies will match with medicinal chemist 's natural intelligency, but for sure, never go beyond. This manuscript tries to assess the impact of the artificial intelligency on drug discovery to day.
\end{abstract}

Key words : Artificial Intelligence, Chemistry, Drug Discovery, Deep learning machine. 


\section{1-Introduction}

Drug discovery is a hugely expensive and often frustrating process. Medicinal chemists, using their knowledge of how a simple structural modification within a molecule, may affect molecular properties, synthesize tirelessly and screen countless numerous analogues with deep energy and often with frustration, since most are failure. Coming up with new high value added molecules is more than an art. Synthetic chemists can explore only a tiny slice of the huge space of possibilities, estimated as many as $10^{60}$ potentially drug-like molecules (Reymond 2016). To-day it is possible to create more than 26 million molecules containing no more than 11 carbon atoms, nitrogen, oxygen or fluorine, using conventional synthetic methods and that only 63850 (0.24\%) have been synthesized (Fink 2007). Moreover $49 \%$ of approved drugs between 1982 and 2002 were natural products derivatives. No doubt, drug therapeutic discovery can look forward to a bright future. No doubt also that deep-learning programs trained on large amounts of experimental data and chemical literature will help the emergence of novel compounds.

Nevertheless, over the last few decades the field has seen a series of supposedly revolutionary technologies, from computational design to combinatorial chemistry and highthroughput screening, that have automated the rapid production and testing of multiple molecules. Each has proved somewhat helpful but limited. Till now none have, "magically get you a new drug." This reasoning raises the question "Can artificial intelligency revolutionize drug discovery?

This question leads to other key issues :

-Can artificial intelligency solve any problem that a person would solve by thinking ?

-What can expect a medicinal chemist from artificial intelligency?

-Is artificial intelligency the future of drug discovery or just a way to save time?

-Are applications of artificial intelligency to drug design, not over-hyped expectations?

This paper seeks to answer the above questions. 


\section{2- Dialogue between the chemist designer and the deep-learning}

\section{machine.}

One of the biggest challenge the medicinal chemist has to face is to establish meaningful communications with the deep learning machine, since man and machine are two entities thinking at dramatically different speeds and with extremely disparate capabilities. To illustrate this finding, consider those two statements :

\section{Lavandulol is a molecule}

\section{Lavandulol is a natural fragrant molecule}

The second gives us more information since it tells that lavandulol is "natural " and "fragrant " in addition to be a "molecule". How can we quantify the difference between these two statements ? Can we have a mathematical measure that tells us how much more information second statement have as compared to the first? This point represents the first challenge to overcome.

A more sharper challenge is to ask the deep-learning machine to analyse possible relationships between random variables and furthermore define the strength of these relationships. A representative example is given on scheme 1.

\section{Thalidomide is a chiral molecule \\ Two Enantiomers}

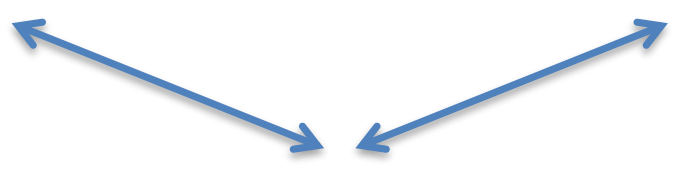

Optical Rotation 
In this deterministic experiment, we always know the resulting outcome, namely chirality which induces the presence of two enantiomers, characterized by a specific optical rotation. In this case no new information are gained from observing the outcome.

Imagine a medicinal chemist drug designer who has a deep-learning machine at its disposal which can provide him, accumulation of pharmacological data, in silico evaluation of absorption, distribution, metabolism, excretion, toxicity (ADMET), de novo drug design, activity scoring, virtual scoring, quantitative structure activity relationship analysis. Given the number of chemical and biological number of parameters, the difficulties and challenges faced to connect together the outcomes of each of these parameters, are overwhelming .

To come up with an algorithm, which efficiently allows to interface medicinal chemist reasoning and the machine capabilities, is like trying to solve a non linear equation of $n$ unknown variables, which most of the time appear chaotic, unpredictable, or counterintuitive.

How this chemist could engage an organized dialogue with the machine ? Should he ask the machine to provide or suggest him an original chemical structure never met in the living world, which interacts with a specific biological target involved in an important pathology with unmet need, without side-effects and easy to synthetize ?

Such base-case projection explicitely addresses the concept of "General Artificial Intelligency", which remains in the realms of science fiction. In contrast, "Narrow Artificial Intelligency " which focuses on specific tasks, could be successfully applied at different stages of drug discovery to speed up the process of research and reduce the costs. As an example, "narrow artificial intelligency platforms" could be useful tools to generate and analyse extensive collections of chemical and biological outcomes data. One can note the example of novel cloud-based proteome screening platforms, which predict protein-drug interactions, earlier in drug discovery process (Olgac 2019).

As pointed out by Shrödinger in his book "What is life ?" the hallmark of a living system is its ability to maintain or to reduce its entropy by increasing the entropy around it. When a drug binds a specific biological target, whatever the predictions come from "natural human intelligency" or from "artificial intelligency", its entropy decreases, and as a result, a disorder must increase somewhere else in the cell. But in any cases, both intelligencies cannot defy the second law of thermodynamics, both have to work intelligently. 
'Thermodynamically speaking, artificial intelligency can match with natural intelligency, but for sure never go beyond.

\section{3- The most vital issue for the medicinal chemist.}

"Artificial intelligency" will have surpassed Human Being Natural Intelligency in terms of drug design creativity, only when it comes up with a new blockbuster that mother nature never provides, and which molecular structure and biological effects, could expand human understanding of the living world. This event is unlikely to happen, because, since life began and evolved, Human Beings have always attempt to copy mother nature in the design of the major biological molecules at the origin of life.

Unless to conceive a new biological life model based on novel organic molecules which have nothing to do with the two universel constituents of life, proteins and nucleic acids, there is little hope that artificial intelligency could suggest such futuristic blockbusters. At this point the crucial question is: Is there an essential boundary between the inert material and the living? Some people simplify living things, determining essential elements in terms of genome or metabolic networks (Top and Down strategy), in contrast some want stimulate the origin of life in the prebiotic chemistry, in trying to reconstruct complex elements of the living from simple elements (Upward bottom-up strategy). Whatever the selected strategy, the weigth of the artificial intelligency is the same. Many misunderstand the significance of what is often referred to Artificial Intelligency, and some think that learning machines could senses, reason and think like people. Giving to the best biologists and chemists in the world, the most advanced tools and the whole knowledge of synthetic chemistry, to create a robot able to suggest the design of complex molecules like palytoxine (Armstrong 1989) and its 64 chiral centers, synthesized by dinoflagellates during the mid-triassic, remains within the world of science fiction.

\section{4-Do we need more Creative Medicinal Chemists or more Al learning machine Developpers?}

To day, to overcome the high attrition rates in drug development, big pharma industry collaborate with Artificial Intelligency industries to improve the efficiency of the drug development process; around 127 start-ups are using Artificial Intelligency in drug design 
(Drug Development \& delivery 2018). Bearing in mind the role of Artificial Intelligency in the actual drug discovery development, the striking question to answer is: do we need more researchers to make sense of the advancing science, or do we priviledged deeplearning machines and artificial Intelligency development ? Can organs-on -chips (Kimura 2018) which offer a potential alternative to traditional animal testing and constitute an ideal system for drug discovery, or bioprinting technology based on 3D printable bio ink (Donderwinkel 2017) which enables life growth of human cells by printing parts of the body for testing drugs, make possible the discovery of new drugs ? A rapid survey on recent litterature reveals that the most recent and decisive breakthrough in the antibiotic field are the discovery in 2015 of the powerful teixbactin (Ling 2015) and related analogues malacidins (Hover 2018), those new antibiotic drugs are essentially the result of the creativity of human chemist brains. The chances that next penecillin will just fall into our laps through the only saving grace of Artificial Intelligency are slim ? The picture is even starker if, as reported by some thinkers, there are fewer big inventions left and we are doomed to a dismal economic future (Gordon 2016).

Maybe, besides more researchers and more artificial intelligency, that is need, is policies, including tax incentives that will encourage investments into more research ?

\section{Conclusions}

We will say: Artificial Intelligency has surpassed "human being natural Intelligency" in terms of drug design, when a deep learning algorithm will outwit the most accomplished "drug designer chemist" in coming up with a new drug for the welfare of humanity ? This fateful day should lead us to fear the worst. The creativity of the medicinal chemist will have been gradually replaced by the absolute diktat of artificial intelligency, and its impressive array of technologies: deep learning machines, machine leaning, statistic, data mining. The risk for the future will be to lose pure creative medicinal chemists genius, who before the era of Artificial Intelligency, did not hesitate to venture into the more farstretched synthetic projects such as "Synthesis of Anthropomorphic Molecules: The NanoPutians." (Chanteau 2003) or to embark on complex natural products synthesis. Is Artificial Intelligency could have help Leo Sternbach (Baenninger 2004) in its discovery of 
valium, a drug which jumps from nowhere, which have opened the way to benzodiazepine drugs, a psychoactive family of drugs used worlwilde.

Concluding we can truly say: artificial intelligency can bring speed and reliability to drug discovery process, its represents an additional tool for medicinal chemists which can harnessed with their logic creative insight. As the years go by, the support of artificial intelligency in drug discovery, will become more efficient and more productive but will never substitute for creative medicinal chemists, who will remain masters in molecular drug design. At this point, one can ask: should organic chemists focus more on what and why rather than on how to make it?

\section{Acknowledgments.}

Institut de Biologie du Dévelopement de Marseille (IBDM), Aix Marseille University and CNRS-UMR 7288, are greatly acknowledged for financial support. We thank Mrs Mair Richards for manuscript's english revision.

\section{References}

Armstrong RW, Beau J-M, Cheon SH, Christ WJ, Fujioka H, Ham WH, Hawkins LD, Jin H and Kang SH (2009).Total synthesis of palytoxin carboxylic acid and palytoxin amide. J.Amer.Chem.Soc. 111, 7530-7533.doi 10.1021/ja00201a038.

Baennninger A.(2004) Good chemistry : The life and legagy of valium inventor Leo Sternbach. New York : McGraw-Hill Editors., 2004. ISBN 0-07-142617-5.

Chanteau S H and Tour JM. (2003) Synthesis of anthropomorphic molecules: The Nanoputians. J. Org. Chem., 68 (23), 8750-8766. doi: 10.1021/jo0349227)

Donderwinkel SH, Van Hest, JCM and Cameron NR.(2017). Bio-inks for 3D bioprinting: recent advances and future prospects. Polymer Chemistry, 31, 4451-4471 doi 10.1039/C7PY00826K 
Drug Development \& delivery (2018). Artificial intelligence-3Ds Powering Al in Drug Discovery-Domain Expertise, Deep Learning \& Data, BenchBlog. https://blog.benchsci.com

Fink T and Reymond J-L.(2007). Virtual exploration of the chemical universe up to 11 atoms of C,N,O,F: Assembly if 26.4 million structures (110,9 million stereoisomers and analysis for new ring systems, stereochemistry, physicochemical properties, compound classes and drug discovery. J.chem.inf.model. 47, 342-353. Doi: 10.1021/ci600423u

Gordon RT (2016). The Rise and Fall of American Growth: The U.S. Standard of Living since the Civil War, Princeton University Press, (ISBN 9780691175805)

Hover BM, Kim SH, Katz M, Charlop-Powers Z, Owen JG, Ternei MA, Maniko J, Estrela AB, Molina H, Park S, Perlin DS, Brady SF. (2018) Culture-independent discovery of the malacidins as calcium-dependent antibiotics with activity against multidrug-resistant Grampositive pathogens. Nature Microbiology. 3 (4): 415-422. doi: 10.1038/s41564-018-0110-1

Kimura H (2018) . Organ/body -on-a-chip based on microfluidic technology for drug discovery. Kimuri H, Sakai Y, Fujii T. Elsevier Editors 2018.

Ling LL, Schneider T, Peoples A J, Spoering AL, Engels I, Conlon BP, Mueller A, Schäberle TF, Hughes DE, Epstein S, Jones M, Lazarides L, Steadman VA, Cohen DR, Felix CR, Fetterman KA, Millett WP, Nitti AG, Zullo AM, Chen C, and Lewis K. (2015). A new antibiotic kills pathogens without detectable resistance. Nature.517: 455-459. Doi 10.1038/nature 14098.PIMD 25561178.

Olgac A, Türe A, Olgac S, and Möller S.(2019.) Cloud basedhigh throughput virtual screening in novel drug discovery. Springer open COST J. Kolodziej and Gonzalez-Velez Editors. pp 250- 278. 2019 ISSn 0302.9703. https//doi.org/10.100/978-3-030-16272-6.

Reymond J-L.(2015) The chemical space project. Acc. Chem. Res 48 :722-730. https//doi.org $10.102 / \operatorname{ar} 500432 k$ 
